\title{
AN IMPACT ANALYSIS OF SUSTAINABLE MANUFACTURING IN INDIA: A CASE STUDY OF GLIMPSE
}

\author{
Sachin Bhat \\ Assistant Professor, K.L.E. Society's J. G College of Commerce, \\ Hubballi, Karnataka, India. \\ Dr. Sangamesh Hugar \\ Assistant Professor, K.L.E. Society's J. G College of Commerce, \\ Hubballi, Karnataka, India.
}

\begin{abstract}
Manufacturing units of a country plays a vital role in the growth of an economy. The development of this sector is a key indicator of the economic strength of a country. It helps in raising productivity, generating employment and also supports creating fruitfulness in job and other sectors of the economy.

Make in India was inaugurated by our Prime Minister, Narendra Modi on 25 September 2014, to encourage companies to manufacture their products in India. He has launched this ambitious campaign with an aim to show the country into a worldwide manufacturing hub.

This is a world marketing strategy conceptualized by the PM of India to attract investments from businesses everywhere the planet and reworking India into a worldwide manufacturing Hub. For promoting this campaign, the online portal, logo and brochures are used for detailing 25 priority sectors of the economy.

The main motto behind this initiative is to focus on job creation, improving living standards, skill development and innovation and to align India's manufacturing sector into the Global Value Chain by encouraging Public Private Partnership (PPP), Joint Ventures (JV), Foreign Direct Investment (FDI) inflow, and advancing Ease in Doing Business $(E D B)$. Higher education will also play a significant role in improving the quality of Research and Development $(R \& D)$. This scheme focuses on acceleration of economic growth to the new level and to drag back the economy from clutches of recession. Currently India's GDP is heavily tilted in favors of service sector. The secondary data collected from different sources like journals, magazines, annual report etc.
\end{abstract}


Keywords: Job creation, Skill Development, Research and Development, Manufacturing.

Cite this article: Sachin Bhat and Sangamesh Hugar, An Impact Analysis of Sustainable Manufacturing in India: A Case Study of Glimpse, international journal of management 11(12), 2020, pp.1049-1059.

http://iaeme.com/Home/issue/IJM?Volume=11\&Issue $=12$

\section{INTRODUCTION}

The Make in India crusade was started by Prime Minister Narendra Modi in India on September 25, 2014 out of a capacity at the Vigyan Bhavan. Fundamentally, it is an activity of the Indian Government to support global and homegrown businesses to make their items in India. To be sure, it would like to make India as a significant assembling center point. India achieved milestone after first quarter of 2015, as the top destination globally for investment, beating our next to door neighbor as well as the States.

The major outcome from this campaign is that it will create around one hundred million job opportunities for youths in India over time. The main objective is to take a share of manufacturing in country's gross domestic product from $16 \%$ to $25 \%$ by 2022 , as pronounced in the national manufacturing policy. The Major objective of this scheme focuses on twentyfive sectors. These areas are Automobiles, materials and Garments, Biotechnology, Wellness, Defense, Manufacturing, Ports, Aviation, vehicle parts, synthetic substances and Electronic System, Food Processing Mining, Media and Entertainment, IT and BPM, Pharmaceuticals, Renewable Energy, Roads and Highways, Railways, Thermal Power, Oil and Gas, Space, Leather, Construction.

\subsection{Why Make in India Campaign is important?}

For the purpose of re enforcing the traditional practices and creating the new vision forconverting the India into a global manufacturing hub, the NDA government last year in iterated program that is run nationwide by the slogan of "Make in India" with the motive to facilitate investments, faster innovation, growth and build world class manufacturing infrastructure.

Now the question arises? why it's important to focus upon manufacturing sector, as we all know that it does makes a major impact as far as India is concerned it's always in mind that India is primarily and most importantly an agriculture oriented economy but the industry which has the most prominent contribution in the economy has also held its place quite firmly, but it was the manufacturing industries which was having less care of although it is the most important driving force or the one which needed gear up!

We have always been blessed by nature for the necessary raw materials, India is still acountry who is having ample resources, the human resourceis most dynamic, extraordinary and the service sector is touching another level of heights. The one and the onlything amiss was the manufacturing sector - a sector whichcould integrate the raw materials of the produce and the endservice.

Four pillars of make in India Manufacturing in India is that the main vision of the govt and results in national development. The initiative is constructed on four pillars which are as follows:

\subsection{New Processes}

The government is introducing several reforms to produce and nurture possibilities for getting FDI and foster business partnerships. This reform is additionally aligned with parameters of World Bank's simple Doing index to enhance India's ranking thereon. Make in 
India recognizes simple doing business because the single most vital factor to market entrepreneurship. A number of fruitful initiatives have been already undertaken to ease of doing business.

\subsection{New Infrastructure}

The government is interested in developing industrial corridors and build and develop smart cities, create world class infrastructure with advanced technology and high-speed fiber optic communication platform. Innovation and research activities are supported by a fast-paced registration system and improved advance infrastructure for IPR registrations. Along with the development of infrastructure, the training for the skilled workforce for these sectors is also being implemented.

\subsection{New Sectors:}

This campaign has identified twenty-five sectors to market with the detailed information is being shared through an interactive and structured web portal. The government has allowed $100 \%$ foreign direct investment in Indian Railways and removed restrictions for the purpose of creating greater impact. It has also increased the foreign direct investment to $100 \%$ in defence and Pharmaceutical sector.

\subsection{New Mind-set:}

This initiative intends to vary by bringing a paradigm shift within the way Government interacts with various industries. It will specialist in acting as a partner within the economic development of the country alongside development in corporate sector.

\section{OBJECTIVES OF THE STUDY}

- To study the role of Make in India scheme as a driver for growth in electronics sectors.

- To study how India is converting into global manufacturing hub.

- To study Make in India Strategy for Electronic Products.

- To analyze impact of Make in India program on electronic industry.

- To study the achievements of Make in India program in electronics industry.

\section{METHODOLOGY}

The present paper investigates the challenges posed to the 'Make in India' campaign by the manufacturing sector in India. Secondary data from different sources like journals, magazines, Census of India, Government reports, surveys and websites have been taken to support the points. An Exploratory research was chosen in order to develop a profound understanding of the research topic and obtain in depth data about the research objectives.

\section{ANALYSIS AND INTERPRETATION}

\subsection{Sector highlights}

- India's IT area showcase is anticipated to reach US\$ 100 billion by 2025.

IT-BPM sends out from India are evaluated to reach US\$ 126 billion (IT administrations US\$ 69 billion; BPM - US\$ 28 billion; Engineering and R\&D administrations (ER\&D) US\$ 80.94 billion) in FY 19; the Indian IT-BPM industry remains at US\$ 181 billion (FY 19); and the business is biggest manager of workforce which is around 4 million individuals.

During April-July 2019, fares of PC equipment and extras and customer hardware remains at US\$ 113.99 million and US\$ 148.90 million, separately.

By 2020, the Government of India means to engage in any event one individual for every family unit with computerized proficiency abilities. For an equal, the govt has propelled different computerized skilling activities that are pointed toward engaging residents with the ability of utilizing IT and cell phones. 
By 2022, the IT business in India is relied upon to expand work to around 2 million direct contracts and 7.6 million roundabout contracts.

Exports of buyer hardware from India came to US\$ 148.90 million from April-July'19. The top fare goals were USA (US\$ 39.89 million), UK (US\$ 3.68 million), Singapore (US\$ 10.17 million), Israel (US\$ 6.91 million) and Belgium (US\$ 6.10 million).

In the innovation driven new companies, India positions third on the planet (4,750 innovation new businesses in 2016)

India has generally alluring and ideal government strategy and guidelines to help for the hardware and IT industry.

The business offers a scope of assortment of administrations, from low-end application improvement to very good quality coordinated data innovation arrangements over different verticals, with a well-created merchant base.

The Indian data innovation and programming industry sticks to quality procedures and benchmarks, with numerous organizations adjusting activities to universal principles.

Software innovation parks and extraordinary monetary zones in India give a reasonable land space for IT organizations.

Exports of buyer electronic products from India came to US\$ 362.11 million of every 2017-18. The top fare goals were USA (US\$ 95.61 million), Israel (33.86 million) and Belgium (US\$ 30.50 million), UK (US\$ 62.97 million), Singapore (51.87 million).

\subsection{Ongoing Developments}

The administration includes a solid represent considerable authority in changing the nation into money less economy. Various government impetuses, for example, referral reward plan to advance the utilization of BHIM application, zero help charge on railroad tickets booked on the web and dispatch of Aadhaar-based portable application are pointed toward empowering computerized installments inside the nation. May 2019, the Ministry of Electronics and Information Technology propelled the Start-up Hub (MSH) entrance.

Gadgets and computer software export promotion council and The Electronics and Computer Software Promotion Council (ESC) was shaped to supply a stage for India's IT and industry. With fares to very 200 nations, The Electronics and Computer Software Promotion Council (ESC) has effectively guided the heading of India's gadgets and programming sends out. ESC offers an extensive database of industry organizations, and items and capacities of every significant player.

The board encourages import/send out coordinated efforts, joint endeavors, subcontracting tie-ups, and innovation moves for industry players.

It gives access to distributed reports on business sectors, items and exchange measurements, business openings, and government approaches.

The IT-BPM industry in India remained at US\$ 181 billion FY19.

\subsection{Development of Electronics Sector (Source: MeitY Annual Report 2017-18)}

The all-over worldwide gadgets equipment industry is about US\$2 Trillion, out of which, India's Production was about US\$ 47 billion during the year 2016-17. The household utilization in India was about $\$ 86.4$ billion during the year 2016-17, while trades were about US\$ 6 billion.

The present worth expansion in the segment ranges from 5-30\% in India, contingent on the constituent of significant worth chain. For instance, it is around $25-30 \%$ in parts, while, it is approx. 5-15\% at SKD get together level.

The Electronics area has a few verticals as far as its principle constituents. At present, the accessibility of Production information of this division is constrained. 
The generation profile of the Electronics Sector is as per the following

Table 1

\begin{tabular}{|c|c|c|c|c|c|c|c|}
\hline SI. No. & Items & 2014-15 & 2015-16 & 2016-17 & $\begin{array}{c}\text { 2017-18 } \\
\text { (Estimated } \\
\text { till March } \\
\text { 2018) } \\
\end{array}$ & $\begin{array}{l}\text { 2017-18 (Actual } \\
\text { till March 2018) }\end{array}$ & 2018-19 \\
\hline 1. & \begin{tabular}{|l} 
Consumer \\
Electronics
\end{tabular} & 55,806 & 55,765 & 64,742 & 73,524 & & \\
\hline 2. & $\begin{array}{l}\text { Industrial } \\
\text { Electronics }\end{array}$ & 39,374 & 45,083 & 62,214 & 69,057 & 70300 & $\begin{array}{l}80850 \\
\text { Est. }\end{array}$ \\
\hline 3. & $\begin{array}{l}\text { Computer } \\
\text { Hardware }\end{array}$ & 18,691 & 19,885 & 20,382 & 21,401 & & \\
\hline 4. & Mobile Phones & 18,900 & 54,000 & 90,000 & $1,32,000$ & & \\
\hline 5. & \begin{tabular}{|l} 
Strategic \\
Electronics
\end{tabular} & 15,700 & 18,055 & 20,760 & 23,562 & 23562 & 28270 \\
\hline 6. & \begin{tabular}{|l} 
Electronic \\
Components
\end{tabular} & 39,723 & 45,383 & 52,099 & 58,351 & 59132 & 67706 \\
\hline 7. & $\begin{array}{l}\text { Light Emitting } \\
\text { Diodes (LED) } \\
\end{array}$ & 2,172 & 5,092 & 7,134 & 9,630 & 9630 & 13,000 \\
\hline & Computed Total & $1,90,366$ & $2,43,263$ & $3,17,331$ & $3,87,525$ & & \\
\hline
\end{tabular}

2018-19

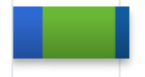

2017-18 (Actual till March 2018)

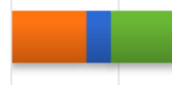

2017-18 (Estimated till March 2018)

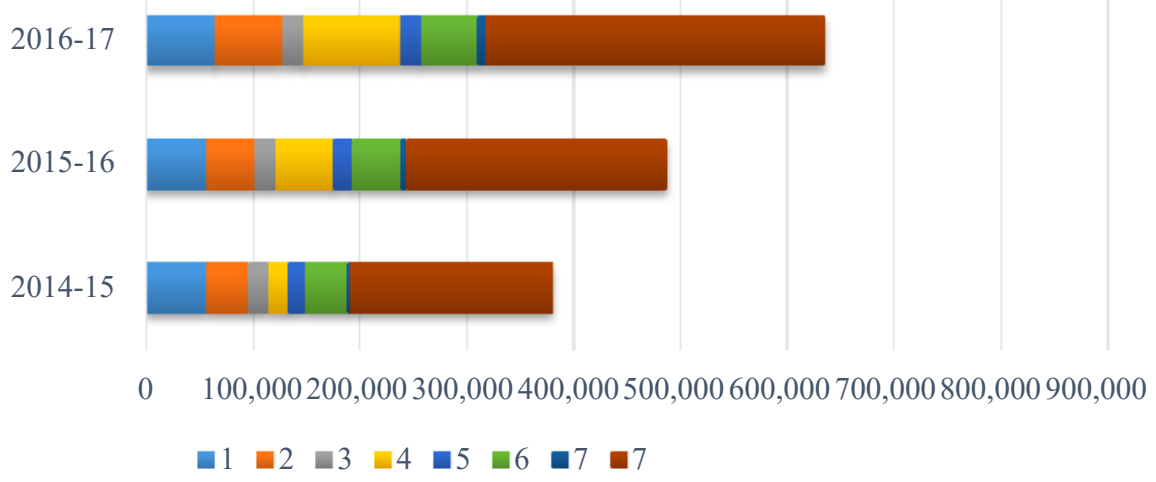

Figure 1

The all-over generation of the previously mentioned verticals of gadgets division in India is evaluated to be about Rs.3, 87,525 crore in 2017-18, contrasted with Rs.3,17,33 I crore in 2016-17, showing a development of about 22\%. Asa consequence of different activities taken by the Government and endeavors of Industry, creation of gadgets in India has demonstrated noteworthy development during the most recent three years. 


\subsubsection{Shopper Electronics}

The Flat board TV showcase has indicated a significant development over the most recent 5 years because of digitalization of communicate division and expanded reasonableness because of decrease in cost. The generation of LCD/LED TVs got a lift and has expanded to 16.0 million numbers esteemed at about Rs. 26,400 crores in 2017-18, from 14.5 million Nos. esteemed at about Rs. 23,925 crores in 2016-17, showing a development pace of about $10 \%$. The creation for Home Theaters is evaluated to observe a development of about 0.76 million nos., esteemed at about FRs.924 crore in 2017-18, compared to 0.7 million nos., esteemed at Fts. 840 crores in 2016-17. Shopper Durables/Home Appliances: This sub-part containing Air Conditioners, Washing Machines, Refrigerators and Microwave Ovens has indicated a development pace of about $17.2 \%$ with an estimation of Rs. 44,590 crores in 2017-18, as against $13 \mathrm{~s} .38,035$ crore in 2016-17. According to CEAMA, the general generation of this portion of gadgets industry, including Consumer Durables/Home Appliances was Rs.64,742 crore in 2016-17 and is evaluated to develop by $13.6 \%$ to about $13 \mathrm{~s}$. 73,524 crores in $2017-$ 18.

\subsubsection{Mechanical Electronics}

The absolute creation of Industrial Electronics during 2017-18 is assessed to be about Rs.69,057crore, as against!3s. 62,214 crores during 2016-17, displaying a development of about $11 \%$. Mechanical Electronics portion is reliant on in general development in GDP and pace of development of assembling. There has been relentless increment in development rate from 5.6\% to 8.2\% in GDP from QI of 2017-18 and QI of 2018-19.

what's more, producing is becoming relentlessly above $7 \%$. In like manner gauge for development of Industrial Electronics for 2017-18 is modified to $13 \%$ (I3s.70,300cr) and 15\% for 2018-19. This area is additionally seeing development due to enhanced digitization and Robotics Applications in Industry 4.0.

\subsubsection{PC equipment}

PC equipment contains Desktops, Laptops, Note Books, Tablets/Net Books, Servers, other processing gadgets, Microprocessor based frameworks and Computer peripherals. With the approach of innovation, assortments of mobiles, viz., advanced mobile phones and hand-held gadgets with the abilities/power/highlights of PCs have been entering the market. Subsequently, the utilization of customary Desktops has reduced for individual purposes. In any case, the use of the PCs and its peripherals in business, mechanical and Offices is probably going to develop at a relentless pace. The Indian PC equipment Industry has been experiencing an adjustment in its item synthesis. The creation of PC equipment expanded from Fts. 19,885 crores in 2015-16 to F3s. 20,382 crores in 2016-17, showing a development pace of $2.5 \%$.

It is relied upon to reach to about Rs. 21,401 crores during the year 2017-18, showing a development pace of about $5 \%$.

\subsubsection{Cell Phones}

Portable handsets and segments producing action proceeded to accelerate during 2017-18. Upwards of 120 assembling units of Mobile handsets and parts have been set up in India during the previous three years. Out of these, around 59 units are delivering versatile handsets and rest of them are occupied with assembling different segments of portable handsets, for example, chargers/connectors, battery packs, wired headsets, mechanical parts, USB links and so on spread across India.

The generation of Mobile handsets developed to approx. 90,000 crores in 2016-17 contrasted with.54,000 crore in 2015-16, showing a development pace of about $66 \%$, though, the creation of Mobile handsets is assessed to be about 1,32,000 crores in 2017-18. In volume 
terms, generation developed to around 175 million of every 2016-17, more than 110 million out of 2015-16, displaying a development of about $60 \%$, which is additionally evaluated to develop to 225 million units in 2017-18.

A few activities have been taken during the year prompting critical interests in new assembling tasks. A portion of the significant initiatives like Phased Manufacturing Program (PMP) for versatile handsets have assumed a key job to change the assembling space.

\subsubsection{Vital Electronics}

Gadgets is a key territory of barrier innovations and become an imperative component of almost all the weapon frameworks, stages and gear planned and created for protection reason.

According to ELCINA, the creation of Strategic Electronics has developed from Rs. 18,055 crores during 2015-16 to Rs.20,760 crore during 2016-17. The creation is assessed to be about Rs.23,562 crore during 2017-18, exhibiting a development of about $13.5 \%$ more than 2016-17.

Since 2017 there has been center around expanding guard creation, $R \& D$, in-digitization just as help to MSMEs and new businesses. All the DPSUs have been actuated and doled out aggressive focuses for digitization. Be that as it may, the draft DPP 2018 has set an objective of Rs. 1,70,000 crores by 2025 and fares of Rs.35,000 crores. This requires development pace of $17-18 \%$ every year throughout the following 7 years. In view of this it is evaluated that Strategic Electronics will accomplish a development of 19-20\% during 2018-19 (Rs.28,270cr). This is additionally in light of the fact that substance of IT and gadgets is developing in guard gear.

\subsubsection{Electronic Components}

According to ELCINA the household creation of electronic parts for the year 2017-18 is assessed to be about Rs.58,351 crore versus Rs.52,099 crore during 2016-17, displaying a development of about $12 \%$.

The electronic part industry has seen a positive move in contrast with the assessed pattern. The section has recorded a generation volume of Rs. 59132 crores as against the prior assessed figure of Rs. 58351 crores. The plausible purpose behind this presentation might be credited to expanded interest for by and large gadgets in the nation. Government has as of late forced custom obligation on certain completed hardware merchandise along these lines giving a positive differential to their assembling in the nation. The custom obligation on PCBAs has likewise been expanded in last three-four years with an intention for reinforcing the residential EMS and Component section in India. The PCBAs for the assembling of cell phones has additionally made a positive biological system for segment fabricating. The fragment is relied upon to post CAGR of $14 \%$ during the year 2018-19 with assembling figures of Rs. 67706 crores.

It is, in any case, vital that a noteworthy offer (over $70 \%$ ) of this part creation is being sent out leaving about $25 \%$ for local utilization, which is utilized in residential electronic hardware generation. Dominant part of electronic segments is not made in the nation and must be imported. In that capacity, Government has been taking proactive measures for advancement of local assembling of electronic parts.

The Indian electronic part creation is overwhelmed by electromagnetically segments (like printed circuit sheets, connectors, and so forth.,) with $29 \%$ offer and inactive segments (like injury segments, capacitors, resistors, and so forth.) with $24 \%$ offer. Further, the portions of dynamic parts (like ICs, diodes, transistors, picture tubes, and so forth.) and the related components (like optical circle, magnets, RF tuners and so on.) of the segments business are about $18 \%$ and $29 \%$, individually. 
The Electronics Manufacturing Services (EMS) industry in India is developing quickly and key worldwide players just as various residential organizations are operational in the nation. This fragment needs extremely high proficiency of activities to remain gainful. Accessibility of parts and a compelling supply chain is fundamental for EMS organizations for their development. Local organizations have for the most part followed the plan of action of remaining in low-volume and high-blend business portions, where the edges are better.

\subsubsection{Light Emitting Diodes (LEDs) Products}

One of the main thrusts for development in gadgets producing and for developing electronic segments request is the Indian Lighting market. The interest for vitality effectiveness has presented a prompt requirement for more vitality proficient items, for example, Light Emitting Diode (LED) items.

Driven is the decision for cutting edge vitality effective lighting for its technical and monetary excellencies. Numerous nations have set LED as the national vital industry. It is predicted that LED items will have an entrance of about $75 \%$ by 2020 . Driven items spare about $70 \%$ and half vitality, when contrasted with the utilization of Incandescent Lamps (IL) and Fluorescent Lamps (FL), individually. Throughout the years, open doors for Light Emitting Diodes (LEDs) have expanded in vehicles, interchanges, signage, flagging, design and diversion parts. The open door for LEDs in the general space enlightenment fragment of private and business structures is growing quickly.

According to ELCINA, the LED Products fabricating in India is evaluated to reach Rs.9,630 crore in 2017-18, when contrasted with the generation of about Rs.7,134 crore in 2016-17, displaying a development of about $35 \%$.

\subsubsection{Car Electronics}

With the development of Automobile industry and the expanding digitization of automobile controls, Automotive hardware has come to possess a significant fragment of the gadgets business. Car Component Manufacturing Association (ACMA) has anticipated that Indian Automotive Electronics Sector will reach roughly Rs.36,500 crore by 2020 . The worldwide market for car hardware is set to represent 230 Billion US \$ in 2020, from 140 Billion US \$ in 2010. Some key advances utilized in car electronics are as Anti-lock Braking System \&\#40;ABS\&\#41; Body Control Module (BCM), Tire Pressure Monitoring System \&\#40;TPMS\&\#41; Electronic Power Steering (EPS) and so forth., while leaving, cam, wrench and oxygen sensors are the key sensors to be engaged.

\subsubsection{Medicinal Electronics}

Medicinal gadgets assume a pivotal job from the conclusion to the after-care period of restorative treatment and altogether sway moderateness of and access to human services. According to the Annual Report of Department of Pharmaceuticals, the worldwide restorative gadgets showcase is required to develop to US \$ 332 billion by 2020 , from an expected US \$ 228 billion out of 2015 because of rising commonness of incessant infections; maturing populace; expanding pay and reasonableness, bringing about more appeal and usage of social insurance administrations. The Indian market is among the main twenty on the planet by showcase size, and fourth in Asia after Japan, China and South Korea. Indian market is import-ward to the degree of $70 \%$. The Government has additionally found a way to advance this division, which incorporate the accompanying.

- $100 \%$ FDI in medicinal gadgets under programmed course

- Notification of Medical Device Rules 2017

- The improvement of a quality institutionalization system in India that depends on worldwide measures and affirms the quality, security and execution of medicinal gadgets. 
- Several approach measures to address the difficulties of restorative gadgets industry.

- To advance logical and mechanical research in Medical Electronics areas in India, MeitY in relationship with Biotechnology Industry Research Assistance Council (BIRAC) is actualizing Industry Innovation Program on Medical Electronics (IIPME). The Project plans to finance an arrangement of Indian drove pilot Projects that target developments in the multi-disciplinary regions, containing gadgets, building, therapeutic gadgets, human services, programming, calculations and data innovation. MeitY will give a subsidizing backing of Rs. 10.5 crore over a time of 3 years, which has been stretched out till December 2019. Under this program, support is given at Seed, Early progress and changes to scale stages. 25 propositions are being bolstered through BIRAC under the program out of which, 18 recommendations are in Idea-to-PoC arrange, 5 recommendations are in Early Transition stage and 2 propositions are in Transition to Scale organize.

\section{EXPORTS}

Government has taken a few measures for the development of the fares of Electronics Hardware part. Exceptional Economic Zones (SEZs) set up to empower bother free assembling and exchanging for ex-port purposes and EHTP units are the significant supporters of fares.

$100 \%$ Income Tax exclusion on send out benefits is accessible to SEZ Units for a long time, half for next 5 years and half of furrowed back benefits for a long time from that point. The Electronics Hardware Technology Park (EHTP) Scheme is a fare situated plan for undertaking assembling of electronic merchandise.

Product Exports from India Scheme (MEIS) benefits are accessible for fare of electronic merchandise under the Foreign Trade Policy (Error! Hyperlink reference not legitimate.). Different plans for send out pro-motion are Export Promotion Capital Goods (EPCG) Scheme, Duty Exemption and Remission Schemes, Duty Free Import Authorization (DFIA) Scheme, Deemed Exports, etc. Due to the powerful advances taken, trades have been giving indications of progress during the year 2017-18, when contrasted with the year 2016-17.

According to the Directorate General of Commercial Intelligence and Statis-tics (DGCI\&S) data, the fare of electronic products was US \$ 5962.9 Million (Rs.39,979.6 crore) during 2016-17, when contrasted with US \$ 5959.5 Million (Rs.39,063.5 crore) during 201516.

\section{IMPORTS}

According to the DGCI\&S information, the absolute import of Electronics into India in 201617 was US\$ 42,878.9 million (Rs.2,87,558 crore), when contrasted with the import during the first year 2015-16, which was about US\$ 40,939.8 million (Rs.2,68,105.3 crore), an expansion of $4.74 \%$ in US $\$$ terms and $7.26 \%$ in rupee terms.

\section{CONCLUSION}

Make in India is an ambitious project, with an aim for sustainable growth of the economy. With relentless policies towards this end, it is possible to make India the powerhouse of electronics sector in the world.

At this moment, our Prime Minister's Make in India campaign appears to be an imaginative marketing campaign. But there is much thought and even more work that is required to convert this to reality. 


\section{REFERENCES}

[1] Bhat, V., \& Honagannavar, D. V. (2019). A study of Investors' Attitude towards Stock market. Determinants of investment intentions.(An experimental study). International Journal of Research in Social Sciences, 9(3), 454-471.

[2] Honagannavar, D. D., \& Bhat, V. (2019). A Study of Digital Initiative: Scope, Challenges and Perspective of Digital Adaptability, Digital Transparency (an Experimental Study). International Journal of Advanced Research in Engineering and Technology, 10(1).

[3] Honagannavar, D. D., \& Bhat, V. (2019). A Study of Digital Initiative: Scope, Challenges and Perspective of Digital Adaptability, Digital Transparency (an Experimental Study). International Journal of Advanced Research in Engineering and Technology, 10(1). DOI10.34218/IJM.11.11.2020.003

[4] Vittal bhat and ankur vishwakarma, 2020. Examining recent trends of financial statements in commercial banks special references to $h d f c$ and icici bank international journal of management (ijm).volume:11,issue:11,pages:23-30.

[5] Vittal bhat and ankur vishwakarma, 2020. Measurement of quality costs and quality metrics in excel foods pvt. Ltd. - an empirical study.international journal of management (ijm).volume:11,issue:10,pages:1407-1416.

[6] www.makeinindia.com/

[7] http://www.ey.com/Publication/vwLUAssets/ey-make-in-india-april-2016/\$FILE/ey-make-inindia-april-2016.pdf

[8] http://dipp.nic.in/English/Investor/Make_in_India/sector_achievement/Electronics_\&_IT_Sect or_Achievement_Report.pdf

[9] Bhat, V., \& Honagannavar, D. V. (2019). A study of Investors' Attitude towards Stock market. Determinants of investment intentions.(An experimental study). International Journal of Research in Social Sciences, 9(3), 454-471.

[10] http://www.business-standard.com/article/companies/indian-electronics-market-to-be-228-bnin-2020-esdm-117022101200_1.html

[11] http://meity.gov.in/writereaddata/files/Task_Force_Report-new_21211(2).pdf

[12] Bhat, V., \& Honagannavar, D. V. (2019). A study of Investors' Attitude towards Stock market. Determinants of investment intentions.(An experimental study). International Journal of Research in Social Sciences, 9(3), 454-471.

[13] http://dipp.nic.in/English/Investor/Make_in_India/sector_achievement/Electronics_\&_IT_Sect or_Achievement_Report.pdf

[14] http://www.ey.com/Publication/vwLUAssets/ey-make-in-india-april-2016/\$FILE/ey-make-inindia-april-2016.pdf

[15] Honagannavar, D. D., \& Bhat, V. (2019). A Study of Digital Initiative: Scope, Challenges and Perspective of Digital Adaptability, Digital Transparency (an Experimental Study). International Journal of Advanced Research in Engineering and Technology, 10(1). 
[16] http://www.business-standard.com/article/companies/indian-smartphone-sales-to-double-by2020-report-116090601412_1.html

[17] https://ngnsummit.com/indian_market.html

[18] http://www.livemint.com/Consumer/Zanz69Lu3mxh36H7bcDCL/Indian-consumerelectronics-industry-to-touch-206-bn-by-20.html

[19] http://meity.gov.in/DeitY_e-book/edf-book/index.html 